\title{
EPISTEMIC FUNCTIONS OF INTUITION IN DESCARTES
}

\section{INTRODUCTION}

The topic of the paper is the notion of intuition in Descartes' philosophy and its epistemic functions. Descartes introduces his notion of intuition in the context of a description of his method and process of knowing and doing science. Intuition is a significant component of this process. I intend to show that the main epistemic functions of intuition in Descartes' philosophy are differentiated. Intuition is essential not only in the context of justification (the Cartesian synthetic method of proof) but also and especially in the context of discovery (the Cartesian analytic method of discovery). It plays not only a role in the foundation of the cogito but also on different stages of constructing the system of knowledge. Intuition has important functions in grasping simple natures, forming primary concepts, comprehending complex natures, forming primary propositions (including primary principles), and capturing relationships between them and building deductive reasoning (the role of intuition in deduction). Hence, intuition is the foundation for all primary stages of producing knowledge. It is active and important element of pure thinking (a priori) in human knowledge, and science. It fulfils these functions due to its specific epistemic properties. I also argue that intuition is not an autonomous and complete type of knowledge. Nor is it an intuitive thesis, but rather the basis of a justification for theses (including the cogito).

Monika Walczak, PhD, Hab, is an associate professor at the John Paul II Catholic University of Lublin, Department of Methodology of Science, Faculty of Philosophy; address for correspondence: Al. Racławickie 14, 20-950 Lublin, Poland; email: monika.walczak@kul.pl; https://orcid. org/0000-0002-8258-8412. 


\section{GENERAL LOCATION OF INTUITION IN THE MIND AND MENTAL COGNITIVE ACTIVITIES}

In the history of philosophy the term intuition can denote three things: first, an activity, as a simple act, or a process of knowing; second, propositional or non-propositional knowledge; and third, a capacity or a disposition of the human mind (Rorty 1967, 2005; Judycki 2020, 59-66; Walczak 2011, 129). In Cartesian philosophy the first and third notions play the most important role, while the second is controversial, especially given the issue of the completeness and autonomy of intuition as an act providing knowledge.

Several levels are useful in describing intuition. The first is to fix it in the context of the distinction between mind and body; the second is to identify it as one of the cognitive functions (dispositions) of humans; the third is to see it in the context of different activities (forms) of reason (intellect). The next sections are addressed to these issues.

\section{INTUITION AND THE MIND-BODY DISTINCTION}

From the perspective of the mind, the nature of intuition is the same as the nature of the human mind, i.e., res cogitans: totally different and separated from res extensa (body). All features typical of the body, especially extension (materiality), are excluded from the nature of the mind as cognitive capacity. The mind is a pure spiritual principle in humans (Regulae AT 10:415, Rules 42; Morawiec 1967, 196). It is what "doubts, understands, conceives, affirms, denies, wills, refuses; that imagines also, and perceives" (Meditationes AT 7:28, Meditations 19). The mind has two kinds of activity: intellectual and voluntary. Both are cognitive. Intellectual activities (operations) are of three kinds: feeling, imagination and pure understanding, which are the same as intuition. Thus, intuition belongs to the sphere of the human mind, it is of an intellectual nature, and it is a manifestation of pure thought (Regulae AT 10:368, Rules 14).

\section{INTUITION AND DIFFERENT HUMAN COGNITIVE FUNCTIONS}

Intuition can be characterized in the context of different human cognitive functions (capacities). Descartes lists a few such functions:

Where knowledge of things is concerned, only two factors need to be considered: ourselves, the knowing subjects, and the things which are the objects of knowledge. 
As for ourselves, there are only four faculties which we can use for this purpose, viz. intellect, imagination, sense perception and memory. (Regulae AT 10:411, Rules 39)

The nature of intuition is revealed when compared with other cognitive functions, the relationship between intuition and those functions is defined, and their relevance to cognition is determined. This can be done positively by linking intuition to other cognitive functions, and indicating its essential characteristics, or negatively, by contrast showing that intuition does not have a significant relationship with other cognitive functions.

The main definition of intuition, which is cited in many studies on the subject of intuition in Descartes, is the one found in Regulae:

By "intuition" I do not mean the fluctuating testimony of the senses or the deceptive judgment of the imagination as it botches things together, but the conception of a clear and attentive mind, which is so easy and distinct that there can be no room for doubt about what we are understanding. Alternatively, and this comes to the same thing, intuition is the indubitable conception of a clear and attentive mind which proceeds solely from the light of reason. (Regulae AT 10:368, Rules 14)

With regard to this quotation, an elementary, introductory characteristic of intuition in positive and negative aspects, can be given.

Positively, intuition is one of the functions of reason (intellect), but it is the opposite of discursive (ratiocinative) reason (deductive reasoning). The power of intuition manifests itself best in the juxtaposition of intuition and discursive reason. Therefore, I leave this characteristic of intuition to be discussed in the next section. Negatively, intuition would be an act of the intellect that has nothing to do with the senses, which fundamentally differentiates it from feeling, imagining, and memory. The isolation of the intellect in the act of intuition from sensory data determines its cognitive value, making its result obvious and certain because it is not distorted by the senses. Descartes claims that one of the main properties of intuition - "purity" - does not come into contact with the results of sensory operations in a cognitive act. It is thanks to this isolation from sensory data that intuition becomes an intellectual perception of an object, a perception obtained by a force inherent in the nature of the mind. He also calls an act of intellect in which the intellect can act cognitively without reference to any sensory data "pure understanding" (Regulae AT 10:415-16, Rules 42-43; Morawiec 1967, 199-201).

Although there is no connection between intuition and the senses, this does not mean that the senses or other cognitive functions have no cognitive significance. Mind and body, although of a completely different ontological nature, can cooperate in cognitive processes. Both the data of common sense and the data 
of the imagination can be the object of the mind. Thus, if the mind is directed to the data of common sense, feelings are created; if to the data of the imagination, reminders or images follow. Where feelings, memory, images, and intellectual cognition are involved the result of the mechanism of the senses becomes an object of intellectual cognition (Regulae AT 10:416, Rules 43; Morawiec 1967, 199). However, intuition is a kind of perception of the mind whose internal structure does not include intellectual activities that involve interaction with the senses. Intuitive cognition excludes, by its very nature, any data from sensory perceptions, and in parallel excludes a moment of mediation (Regulae AT 10:416, Rules 43; Morawiec, 1967, 200-201).

\section{INTUITION AND DEDUCTION}

Intuition takes place in the context of different activities (forms) of reason (intellect), in particular deduction, leading to an intuition-deduction distinction. Descartes introduces his own notion of deduction, differentiating it from the notion of deduction functioning in relation to Aristotle's syllogisms, which he criticizes for not providing genuine knowledge (Miles 2008, 152-53). He strongly denies the possibility of achieving the truth through syllogistic reasoning, taking into account its form, i.e. that the basis for the conclusions from the premises is a formal structure of sentences with a characteristic order of three terms in the premises. The formal rules of syllogistic reasoning cannot have full cognitive value because considered in relation to the operations of the mind they are something external added to it. They have nothing of intellectual/mental activity in their structure. Descartes also opposes the extensional character of such deductive reasoning. Formalism - understood as depriving a syllogism of its psychological elementsdisqualifies syllogisms, making them useless in the process of reaching the truth. The formal rules of syllogistic reasoning are also harmful because they hinder the operations of the mind by their "darkening." Descartes rejects syllogistic cognition, because in the process of its cognitive operations the mind "takes a holiday." In the end, formal rules of syllogistic reasoning cannot have full cognitive value because the only source of irrefutable cognition that Descartes sees is intuition, which is an act of "pure" mind (Regulae AT 10:405-6, Rules 36-37; Morawiec 1965, 188-189; Miles 2008, 145).

Even though Descartes criticizes the cognitive form of syllogistic reasoning, he does not reject deduction as a cognitive function of the mind. On the contrary,

\footnotetext{
${ }^{1}$ For detailed criticism see MoraWIEC $(1965,182)$ and MiLes $(2008,151-54)$.
} 
he considers deduction the second source and basis of knowledge, after intuition (Regulae AT 10:366, Rules 13). Considering intuition the only act of cognition with certain, self-evident and necessary consequences, he transforms the concept of deduction. He replaces the cognitive form of syllogistic reasoning with the intuitive self-evidence of the grasp of relationships in deductive reasoning, and defines deduction as a longer or shorter sequence of detailed acts of intuition (Regulae AT 10:370, 387, Rules 15, 25; Morawiec 1965, 181, 189). Cartesian deduction consists in moving from the directly self-evident data to more or less distant conclusions; the elements of the deductive sequence and the relationship between them are grasped in acts of intuition (Morawiec 1965, 181, 189). Thus, he regards the notion of intuition as more fundamental cognitively then the notion of deduction (Regulae AT 10:368, Rules 14). In particular, he would insist that the mathematician must proceed by means of intuition if she is to reach valid results (Mursell 1919, 397).

Since deduction is characterized in terms of intuition, one may ask whether deduction can be totally reduced to intuition, or whether deduction-especially direct deduction - is ultimately not the same as intuition (Morawiec 1965, 194-96). In other words, it is a problem of the specific nature of deduction as opposed to intuition. Some Descartes researchers hold that it follows from his entire doctrine of deductive reasoning that any cognitive process that can be classified under the title of deduction will include "movement," since deduction is reduced to the movement of intuitive thought: moving from one part of understanding to another. The movement that accompanies a deduction indicates that the process is not carried out in a completely undivided and simultaneous manner. Rather, it contains a certain order, expressed in a cognitive sequence, and this seems to be the only and essential basis for distinguishing these two functions of one and the same cognitive power- the intellect (Regulae AT 10:369-70, Rules 15; Morawiec 1965, 194; Mursell 1919, 397).

\section{THREE QUESTIONS OF THE “EPISTEMIC FUNCTIONS” OF INTUITION}

The epistemic functions of intuition can be characterized in several ways. First of all, by determining what you can learn through intuition, i.e. what is the object of intuitive cognition, what kinds of objects (theses/theorems, principles) can be known by intuition (for example, the particular, or the universal). Secondly, by the kind of knowledge, i.e. knowledge of what properties, is achieved through intuitive cognition (for example, certain, necessary, immediate, and/or indubitable knowledge). Thirdly, by the function of intuition in the process of cognition: is 
intuition autonomous, separate and complete knowledge? ${ }^{2}$ I will address these issues in what follows.

\section{THE OBJECT OF INTUITIVE COGNITION}

Primary concepts (simple natures), primary theorems (first principles), the relationships between primary concepts and other concepts, as well as relationships between primary theorems and other theorems play an essential role in the characteristics of the object of intuition, which brings to mind the ideal of the deductive system (the fundamentalist concept of knowledge). Although this ideal traditionally belongs more to the context of justification/proof (validation of knowledge, a synthetic method) than to the context of discovery (genesis of knowledge, an analytic method), these categories characterize in Descartes both contexts. On the other hand, there does not seem to be in Descartes a radical distinction between the order of discovery and the order of justification. The latter is, rather, part of the former. For example, the discovery of a concept's value and its estimation (e.g. that it is clear and distinct) is part of the context of the discovery (a method of analysis) but also a part of the context of the justification (a method of synthesis). Seeing Cartesian philosophy of intuition only in the context of justification is misguided since in that philosophy the most fundamental part of method is not the synthetic method of proof ("by which theorems are deduced from self-evident definitions, axioms, and postulates") but the analytic method of discovery ("by which those same theorems (together with the definitions and axioms themselves) were first brought to light by their original discoverers"); it is not the context of justification, but the context of discovery (Discours AT 6:19ff, Discourse, 120ff; Miles 2008, 145).

\section{SIMPLE NATURES AND CONCEPTS AS OBJECTS OF INTUITION}

According to Descartes, every object (thing, substance) can be considered dually: as real, existing, and as known (Regulae AT 10:418, Rules 44). In the first case, the object appears as a non-complex whole; in the second case it is composed of a sum of elements called "simple natures" (Regulae AT 10:422, Rules 46). It is these simple natures that constitute the first kind of object of intuitive cognition. There is a controversy about how to treat simple natures: as ideas/concepts or as

\footnotetext{
${ }^{2}$ See WalcZaK (2016).
} 
elements existing in real objects. The texts on simple natures in Regulae are not clear (Morawiec 1967, 205). A similar problem here is whether the cognition of substance through these simple natures is achieved in the sense of a real-world object, or an idea existing in the mind (Morawiec 1967, 203). I am not going to address this problem here because I believe that intuition does not operate at the level of judgment (which I will try to show in the last point of this text), and that this is where the problem of subjectivity and objectivity of knowledge fully arises.

A simple nature is a conceptual tool of cognition characterized by Descartes in the methodological order of cognition as a term/end of intuitive cognition; that is to say, simple natures are ultimate in the sense that they cannot be further divided (Regulae AT 10:418, Rules 44; Mursell 1919, 398). They determine some limits which contain substances, and by means of which everything is recognized. They are the closest and the most direct object of cognition. They posit the most primary tools for cognizing things (substances) in a clear and distinct way, and what is directly grasped in "pure understanding," i.e., reflective consideration by the intellect of itself (Regulae AT 10:420, Rules 45; Morawiec 1965, 179; 1967, 203-4). For Descartes they are cognitively fundamental because they play a substantial role in the formation of concepts and judgments and are essential material for all other concepts of reality. This is because nothing can ever be understood except these "simple natures" and their relationships (Regulae AT 10:422, 381-82, Rules 46, 21-22; Morawiec 1965, 178). Pure understanding of simple natures is simple and direct, and knowledge about them is a simple and direct act of intellectual intuition (Beck 1952, 73; Morawiec 1965, 180).

Descartes distinguishes three types of simple nature: purely intellectual, purely material and common. The first type includes concepts that denote actions of the intellect and will, i.e. the concepts of cognition, doubt, ignorance, desire, etc. The second type contains concepts that exist only in the body: shape, extension, movement, etc., and simple natures that are attributed to both bodily and spiritual things, e.g., existence, unity, duration, etc. They also include common concepts which allow other simple natures to be connected with each other, and on whose self-evidence conclusions of reasoning are based, e.g., "two things identical to the third are identical to each other etc." (Regulae AT 10:419-20, Rules 44-45; Morawiec 1967, 204; Mursell 1919, 398).

These types and examples of simple natures indicate that they are universals. They arise by means of the distinction of reason and are reached by stating that they are not further subdivided and that they are the end of the distinction. This process of abstraction is one of generalization (Mursell 1919, 399-400). However, the content of "simple natures" is not a general content: it is specific one. The ideas 
of simple natures are therefore neither species nor genera. What does this mean? As I understand it, they are as primary concepts in deductive system - equal, nonreducible and mutually undefinable. Knowing one of them does not mean knowing it is subordinate to another with a broader scope. Rather, it means knowing it alone in itself or in combination with another in what constitutes it. Defining one with the other can be done by comparing opposites, e.g., extension is not a thought; shape is not a movement. Considered in relation to each other, they are mutually non-reducible elements (Regulae AT 10:383, Rules 22; Morawiec 1965, 180).

\section{COMPLEX NATURES: SIMPLE PROPOSITIONS AND FIRST THEOREMS AS OBJECTS OF INTUITION}

Complex natures (Regulae AT 10:399, Rules 32)—i.e., propositions (simple sentences) containing those simplest elements (concepts) that grasp and express relations between them-are also objects of intuitive cognition. These relations can be necessary or accidental (Regulae AT 10:421-22, Rules 45-46). Descartes differentiates between propositions resulting from a combination of simple natures according to their genesis. He distinguishes between, first, propositions based on experience (sensory or intellectual-reflective, i.e. intuition) and second, propositions created by the subject (under the influence of impulse, imagination, or deduction) (Regulae AT 10:422-23, Rules 46; Morawiec 1967, 206). Among such simple propositions (sentences) obtained through intuition are the first principles used as rules of thinking/principles or premises in deductions (Regulae AT 10:370, Rules 15). It seems that some propositions expressing the (necessary) relationship between simple natures are first principles.

First principles are characterized by the fact that they take priority in the cognitive order, i.e., they do not assume any other necessary sentence for their acceptance and many other sentences can be discovered with their help. In addition, for a sentence to function as the first rule in a particular science it does not have to be possible to reduce all other sentences to it and to prove them (Clerselier, AT 4:444; quoted after Morawiec [1965a, 147]). First principles can be divided into two classes: logical and real (Regulae AT 10:399, Rules 32). Logical principles, sometimes called sometimes "eternal truths," are not constructed by the mind. They are discovered. Descartes considers them innate, claiming that God put them into our minds in the form of ideas. Logical principles include, among other things, the principles of contradiction, sufficient reason, identity, causality, and many mathematical truths. They are of a general and formal nature. When considered in terms of methodological functions, they most often function as rules 
of thought/thinking. Considered from a genetic point of view, they do not come from sensory experience, but are a cognitive result of an act of intellectual intuition (Regulae AT 10:369-70, Rules 15; Morawiec 1967, 206; 1965a, 147-48). Real principles are propositions expressing some states of existence. From a structural point of view, they will be the simplest sentences. Functionally, sentences of this type most often serve as starting points in deductive reasoning. The self-evident nature of these sentences does not necessarily have to be independent of the selfevidence of earlier rules (Morawiec 1967, 206). Descartes describes such simple sentences as "absolute." Characterizing them in Regulae, he does not define their nature in detail. They are sentences of the simplest structure and form the basis for deductive reasoning (Regulae AT 10:381, 383, Rules 21-22; Morawiec 1967, 210).

Simple sentences can be characterized in two cognitive aspects: the first concerns their genesis (the process of finding simple sentences), and the second their justification (the way in which they are accepted). Although this acceptance is achieved through intuition, unlike logical principles such sentences do not appear to the mind by themselves. The content of the simple sentence is not captured in stages, i.e. in such a way that you first learn the content of the subject and the predicate, and only then do you conclude that they are necessary or not. Rather, the mind grasps in one moment, directly and immediately, the truth expressed in a simple sentence (Regulae AT 10:421-22; Rules 45-46; Morawiec 1967, 210).

An intuitive grasp of these sentences requires prior cognitive preparation, and it is preceded by a process of analysis (Regulae AT 10:383-84, Rules 22-23). The aim of the analysis is to create the conditions necessary for the free operation of pure reason. Analysis consists in division/distribution and ordering; deciding what is to become an object of intuitive cognition; and in changing obscure and complicated sentences into simple ones. In the case of discovery, an intuitive grasp (an understanding) of such sentences comes up. Descartes considers such analysis one of the most important elements of his method (Miles 2008, 145,154). It was this analysis that led him to obtaining the real philosophical principle Cogito ergo sum (Morawiec 1967, 210). ${ }^{3}$ The example of the cogito as the first principle of philosophy shows how Descartes understands the genesis of such real first principles, where a procedure resembling the Aristotelian induction of epagogé is used (McMullin 2008, 87). The discussion also concerns the justification of the cogito thesis and the question of whether the cogito is an intuition (i.e., roughly, self-evident), or an inference (Newman 2019; Miles 2008, 150). In the context of the debate on the cogito, the question of types of intuition-inner consciousness,

\footnotetext{
${ }^{3}$ On intuition and/in cogito see MiLes (2008, 145-47).
} 
also called internal testimony or conscientia - appears. This kind of intuition is contrasted with two different mental processes: 1) second- and higher-order acts of thinking about thinking (about thinking, and so forth) and 2) discursive analysis through which the logical relations among genera and species are discerned and embodied in formal definitions (Miles 2008, 146).

\section{INTUITION AND DEDUCTION: INTUITION AS KNOWLEDGE OF RELATIONSHIPS BETWEEN PROPOSITIONS}

Complex natures understood as relationships between sentences are also, according to Descartes, objects of intuitive cognition. In his opinion, deduction is a cognitive process based on the linking of simple natures, discovering their mutual relations, and eventually on perceiving them in intuition. Since, as noted in the previous section, it is intuition that plays a fundamental role in the deduction process it is through intuition that the main elements of deductive reasoning are captured (Regulae AT 10:408, 425; Rules 37, 48; Morawiec 1967, 206, 210; 1965, 181). Descartes distinguishes two types of deduction: direct and indirect (Regulae AT 10:406). In direct deduction the link between the conclusion and the principle that is the starting point of the deductive reasoning can be intuitively grasped (Regulae AT 10:407, Rules 37). In indirect deduction the relationship mentioned above is created by means of added elements, i.e., memory (Regulae AT 10:369-70, 408, Rules 14-15, 37-38; Morawiec 1967, 211; 1965, 189). Three elements can be distinguished in direct deduction: the starting point, the conclusion and the relationship between them. Intuition in this type of deduction concerns these three moments. The form and scope of intuition's intervention in the process of direct reasoning makes it possible not only to characterize the conclusion as intuitive, but the whole process of deduction comes down to a simple act of intuition (Regulae AT 10:370, Rules 15; Morawiec 1967, 211; 1965, 193-94).

In indirect deduction, where there are many links in the chain of reasoning, intuition connects the principle with the conclusion only indirectly due to the length of the series of reasoning (Regulae AT 10:387, Rules 25). Intuitively grasping the whole series of deduction links and the conclusions is very difficult (Regulae AT 10:369-70, Rules 14-15). The capacity of the mind is not so great that it can cover in one act of intuition a long deductive series. Nevertheless, the intuitive grasp of the relationship of each individual link in the chain of deduction with the one next to it is the basis for the assertion that the intuitive grasp also includes connecting the last to the first (Regulae AT 10:389, Rules 26; Morawiec 1965, 190). Since we have seen the relationship of each individual link with those that are closest to it, 
we have a sufficient basis, according to Descartes, to say that we also perceived the last to the first relation (Regulae AT 10:369, Rules 14-15; Morawiec 1965, 192-93). In this way, indirect deduction becomes an uninterrupted sequence of individual acts of intuition with an act of intuition that connects all elements together. To make this possible, acts of memory are also necessary. The moment of memory and the moment of its intermediation modify the type of intuition in indirect deduction compared to intuition in direct deduction. The process of understanding is in these two cases slightly different (Morawiec 1967, 211).

\section{EPISTEMIC PROPERTIES OF INTUITIVE COGNITION}

According to Descartes there are some epistemic qualities of intuition that make it the supreme type of cognition/knowledge. The most substantial features attributed to intuition as the privileged kind of cognition/knowledge are the following: certainty, indubitability, purity, attentiveness, clarity and distinctiveness, simplicity, self-evidence, immediacy, and necessity. These are epistemic values that make cognition/knowledge valuable. Most of them can be found in the following excerpt from Regulae:

By "intuition" I do not mean the fluctuating testimony of the senses or the deceptive judgement of the imagination as it botches things together, but the conception of a clear and attentive mind, which is so easy and distinct that there can be no room for doubt about what we are understanding. Alternatively, and this comes to the same thing, intuition is the indubitable conception of a clear and attentive mind which proceeds solely from the light of reason. Because it is simpler, it is more certain than deduction, though deduction, as we noted above, is not something a man can perform wrongly. ... The self-evidence and certainty of intuition is required not only for apprehending single propositions, but also for any train of reasoning whatever. Take for example, the inference that 2 plus 2 equals 3 plus 1 : not only must we intuitively perceive that 2 plus 2 make 4 , and that 3 plus I make 4, but also that the original proposition follows necessarily from the other two. (Regulae AT 10:368-69, Rules 14-15)

\section{CERTAINTY AND INDUBITABILITY}

Cartesian intuition can have a different object. Descartes therefore subsumes under the heading of "intuition" different types of comprehension with diversified structures linked by a feature, or a set of features, that are essential for the certainty of its knowledge/its certainty (Morawiec 1967, 212). Descartes believes that we are able to arrive at a knowledge of things with no fear of being mistaken 
only through two kinds of intellectual activity: intuition and deduction (Regulae AT 10:368, Rules 14). The property of certainty seems to be common to intuition and deduction, including the intuition that constitutes the deduction. However the two kinds of activity have different bases: the basis for the certainty of intuition is self-evidence/evidence and necessity (in direct deduction), while the basis for the certainty of indirect deduction is memory (Regulae AT 10:369-70, 408, Rules 14-15, 37-38).

The notion of certainty can have two kinds of characteristic: positive (attributing something) and negative (denying the features of something). Positively, to be certain means to be entirely sure about something (Discours AT 6:38, Discourse on the Method 130). Negatively, it means to be indubitable - certainty is beyond any doubt. Cartesian "certainty" has two antonyms: uncertainty and dubitability (Regulae AT 10:368, Rules 14).

Now some of these perceptions are so transparently clear and at the same time so simple that we cannot ever think of them without believing them to be true. The fact that I exist so long as I am thinking, or that what is done cannot be undone, are examples of truths in respect of which we manifestly possess this kind of certainty. For we cannot doubt them unless we think of them; but we cannot think of them without at the same time believing they are true, as was supposed. Hence we cannot doubt them without at the same time believing they are true; that is, we can never doubt them." (Objections AT 7:146, Objections and Replies 104)

Certainty is related to a specifically understood purity of mind. It is only possible where a pure mind operates, without contact with the senses (Objections AT 7:145, Objections and Replies 103-4). According to Descartes "certainty does not lie in the senses but solely in the understanding, when it possesses evident perceptions" (Principia AT 9B:7, Principles of Philosophy 182). Purity also concerns objects of intuition that are purely mental. Intuition is combined with absolute certainty, which is ultimately metaphysically founded.

Absolute certainty arises when we believe that it is wholly impossible that something should be otherwise than we judge it to be. This certainty is based on a metaphysical foundation, namely that God is supremely good and in no way a deceiver, and hence that the faculty which he gave us for distinguishing truth from falsehood cannot lead us into error, so long as we are using it properly and are thereby perceiving something distinctly. (Principia AT 8A:328, Principles of Philosophy 290) 


\section{Clarity, DISTINCTIVENESS AND ATTENTIVENESS}

Other epistemic properties of intuition and their differentiation can best be discussed in relation to the object of comprehension. Intuition whose object is simple natures (concepts) and simple sentences (first principles) has slightly different properties than intuition that takes into account the relationship between sentences and constitutes deduction. They are differentiated also depending on whether there is direct or indirect deduction.

Clarity and distinctiveness are features of intuition with regard to the perception (apprehension) of simple natures (concepts) and simple sentences (first principles). Intuition as a kind of perception and the indubitable conception of a clear and attentive mind can only serve as the basis for a certain and indubitable judgement if it is not merely clear but also distinct. Descartes writes:

I call a perception "clear" when it is present and accessible to the attentive mind just as we say that we see something clearly when it is present to the eye's gaze and stimulates it with a sufficient degree of strength and accessibility. I call a perception "distinct" if, as well as being clear, it is so sharply separated from all other perceptions that it contains within itself only what is clear. (Principia AT 8A:22, Principles of Philosophy 207-8)

Attentiveness allows clarity and distinctiveness because it is the source of the "perspicacity" of intellect that enables the mind to grasp simple objects clearly and distinctly. "Discernment" supports the mind again in the process of combining sentences into proof series (Regulae AT 10:400, Rules 33; Morawiec 1967, 201).

There are two possible interpretations of the nature of clarity and distinctiveness of intuition: intentional and phenomenal (Patterson 2008, 232). In the intentional interpretation, clarity and distinctiveness are features of the content intuited. In the phenomenal interpretation they are features of the intuiting. According to the intentional view, clear and distinct intuition is the perception of a content that we find self-evidently true (and God molds our minds so that we find true content self-evidently true). According to the second view, clear and distinct perception is a phenomenally distinctive experience, a kind of feeling that compels the will to assent (God has molded our minds so that we have this experience only when we perceive contents that are true, and thus we are only compelled to assent to truths). In the intentional view we are dealing with a form of rational compulsion, while in the phenomenal view we have a form of brute compulsion to assent to what is clearly and distinctly perceived. God, our creator, has molded our minds in such a way that clear and distinct perception compels us to assent only to truths, 
so clear and distinct perception compels the will to assent the truth (Patterson 2008, 231-32).

\section{SIMPLICITY}

Simplicity is a property of an object of intuition, i.e., simple natures and simple proposition, as well as the act of intuition that is the grasping of such an object. A criterion for considering something simple is the intellectual act that is accompanied by the clarity and distinctiveness of cognitive perception. Descartes writes:

We term "simple" only those things which we know so clearly and distinctly that they cannot be divided by the mind into others which are more distinctly known. (Regulae AT 10:419, Rules 44)

Hence, the boundary of division is determined by the clarity and distinctiveness of the apprehension, i.e., from an epistemological point of view. Simple natures are elements constituting the end of mental analysis of the object of cognition ending with a clear and distinct perception (Morawiec, 1967, 205). However, Descartes also characterizes simplicity from the logical point of view, regarding simple things as being essentially elements (entities) which possess logical priority in the system, i.e. are indefinable, or inferentially prior. Other elements are determined as regards their degree of simplicity (or absoluteness) by the number of steps which separate them from the primary elements of the system in question. He defines the absolute as "whatever has within it the pure and simple nature in question." Correspondingly, we are told that the relative "is what shares the same nature, or at least something of the same nature, in virtue of which we can relate it to the absolute and deduce it from the absolute in a definite series of steps" (Regulae AT 10:381, Rules 21). ${ }^{4}$

\section{SELF-EVIDENCE AND IMMEDIACY}

Self-evidence is the way the truth presents itself. However, it is not clear in Descartes whether self-evidence applies to every kind of intuition as his writings on this matter are not coherent. He sometimes claims that "the self-evidence and certainty of intuition is required not only for apprehending single propositions, but also for any train of reasoning whatever" (Regulae AT 10:368-69, Rules 14-15).

\footnotetext{
${ }^{4}$ See Mursell (1919, 398-99).
} 
In other passages, however, while differentiating intuition from deduction, he holds:

Hence we are distinguishing mental intuition from certain deduction on the grounds that we are aware of a movement or a sort of sequence in the latter but not in the former, and also because immediate self-evidence is not required for deduction, as it is for intuition; deduction in a sense gets its certainty from memory. (Regulae AT 10:370, Rules 15)

More such arguments can be found ${ }^{5}$ so it seems that self-evidence is a feature primarily of intuition whose objects are simple elements (simple natures or simple sentences), and the relationship between simple sentences that constitute direct deduction. However, it is not a feature of the kind of intuition that constitutes indirect deduction as a whole.

The term "immediacy" used with reference to intuition is ambiguous. It means directness, and the fact that intuition is not mediated by other factors but it also means the instantaneous, all-encompassing and synthesizing character of intuition. Directness is guaranteed by the absence of a connection between pure thinking and the senses, or in other words the absence of mediation by sensory data. Descartes seems to have two additional ways of understanding immediacy. In the context of direct deduction intuition covers all its elements (the starting point, the conclusion and the relationship between them) immediately and grasps all its elements at once (Morawiec, 1967, 211; 1965, 193-94). In particular, he links immediacy to the nature of the recognition of relationships between premises and conclusion in direct deduction (Regulae AT 10:370, 389, Rules 15, 26). However, immediacy as an unmediated perception, combined with its self-evidence, determines the distinguished status of intuition as cognition.

\section{NECESSITY}

Necessity is linked with the intuition constitutive of deduction. Descartes does not explicitly attribute the necessity of intuition. Rather, he defines relationships

\footnotetext{
${ }^{5}$ For example in this fragment: "But this distinction [intuition-deduction] had to be made, since very many facts which are not self-evident are known with certainty, provided they are inferred from true and known principles through a continuous and uninterrupted movement of thought in which each individual proposition is clearly intuited" (Regulae AT 10:370, Rules 15). "To this class we must also refer those common notions which are, as it were, links which connect other simple natures together, and whose self-evidence is the basis for all the rational inferences we make" $(R e-$ gulae AT 10:419, Rules 45).
} 
that are required in deductive reasoning between the starting point and the conclusion (inference) as necessary (Regulae AT 10:369, Rules 15; Morawiec 1965, 184). Necessity appears also in the context of complex natures where simple natures are conjoined in simple sentences (Regulae AT 10:421, 425, Rules 46, 48). Of the three ways of linking simple natures mentioned in rule 12 of the "Rules," only deductive connecting is correct because in it the relationships of the elements are necessary, which is related to the special role of intuition (Morawiec 1965, 181). Descartes uses the simple notion of modalities, including necessity. Something is necessary if it cannot be denied without contradiction (Alanen 2008, 366); something is possible if it can be stated without contradiction (Alanen 2008, 367).

\section{IS INTUITION AUTONOMOUS AND COMPLETE KNOWLEDGE?}

Intuition apprehends certain contents (simple natures) or their relationships. Descartes calls such comprehension "understanding" but understanding is not yet knowledge, although it provides a significant basis for obtaining knowledge. The question is whether intuition is a separate, autonomous and complete type of knowledge, and whether it is the only cognitive act needed to formulate and accept the proposition. My thesis is that intuition in Descartes is not an autonomous and complete type of knowledge. Nor it is primarily an intuitive thesis (statement). Rather, it is an essential faculty or act (element) in the process of cognition, which only becomes epistemic when combined with other acts (elements). Intuition serves also as a justification for theses (including the cogito).

The main argument for this interpretation of intuition is the distinction between an intuition and a judgment (intuiting and judging).

Thirdly, these simple natures are all self-evident and never contain any falsity. This can easily be shown if we distinguish between the faculty by which our intellect intuits and knows things and the faculty by which it makes affirmative or negative judgements. For it can happen that we think we are ignorant of things we really know, as for example when we suspect that they contain something else which eludes us, something beyond what we intuit or reach in our thinking, even though we are mistaken in thinking this. For this reason, it is evident that we are mistaken if we ever judge that we lack complete knowledge of any one of these simple natures. For if we have even the slightest grasp of it in our mind - which we surely must have, on the assumption that we are making a judgement about it - it must follow that we have complete knowledge of it. Otherwise it could not be said to be simple, but a composite made up of that which we perceive in it and that of which we judge we are ignorant. (Regulae AT 10:420-21, Rules 45) 
Additionally, judging is different than intuition because it is a matter of intellect while judgment a matter of will (Meditationes AT 7:56-57, Meditations, 39-40).

Next, when I look more closely at myself and inquire into the nature of my errors (for these are the only evidence of some imperfection in me), I notice that they depend on two concurrent causes, namely on the faculty of knowledge which is in me, and on the faculty of choice or freedom of the will; that is, they depend on both the intellect and the will simultaneously. Now all that the intellect does is to enable me to perceive' the ideas which are subjects for possible judgements; and when regarded strictly in this light, it turns out to contain no error in the proper sense of that term. (Meditationes AT 7:56, Meditations, 39)

and

This is because the will simply consists in our ability to do or not do something (that is, to affirm or deny, to pursue or avoid); or rather, it consists simply in the fact that when the intellect puts something forward for affirmation or denial or for pursuit or avoidance, our inclinations are such that we do not feel we are determined by any external force. (Meditationes AT 7:57, Meditations, 40)

If we locate the question of intuition's autonomy and completeness as a type of knowledge in the context of the classical concept of knowledge understood as justified true belief (accepted proposition) we discover that judging (acceptance, rejection) is a necessary component of it. Since intuition does not contain in its structure the act of judging, it is therefore not independent, complete knowledge. The acknowledgment of intuition (intuitive theses) as an independent type of knowledge would require the inclusion of judging in the structure of an intuitive act/cognition, and this seems to be inconsistent with the position of Descartes.

\section{WORKS CITED}

Alanen, Lilli. 2008. "Omnipotence, Modality, and Conceivability." In A Companion to Descartes, edited by Janet Broughton and John Carriero, 353-71. Malden, MA: Blackwell Publishing.

BECK, L. J. 1952. The Method of Descartes. A Study of the Regulae. Oxford: Oxford University Press. Broughton, Janet, and John CARriero, eds. 2008. A Companion to Descartes. Malden, MA: Blackwell Publishing.

DesCARTES, René. Oeuvres de Descartes. Edited by Charles Adam and Paul Tannery. 12 vols. Paris: J. Vrin/CNRS, 1964-76.

DesCartes, René. Discourse on the Method. In The Philosophical Writings of Descartes, edited by John Cottingham, Robert Stoothoff, and Dugald Murdoch, 1:111-51. Cambridge: Cambridge University Press, 1984. 17th printing, 2005. Polish version published as Rozprawa o metodzie. Translated by Wanda Wojciechowska. Warsaw: Państwowe Wydawnictwo Naukowe, 1988. 
Descartes, René. Meditations on First Philosophy. In The Philosophical Writings of Descartes, edited by John Cottingham, Robert Stoothoff, and Dugald Murdoch, 2:1-62. Cambridge: Cambridge University Press, 1984. 17th printing, 2005. Polish version published as Medytacje o filozofii pierwszej. Translated by Jan Hartman. Kraków: Aureus, 2002.

Descartes, René. Principles of Philosophy. In The Philosophical Writings of Descartes, edited by John Cottingham, Robert Stoothoff, and Dugald Murdoch, 1:177-292. Cambridge: Cambridge University Press, 1984. 17th printing, 2005.

DesCarTeS, René. Rules for the Direction of the Mind. In The Philosophical Writings of Descartes, edited by John Cottingham, Robert Stoothoff, and Dugald Murdoch, 1:7-78. Cambridge: Cambridge University Press, 1984. 17th printing, 2005. Polish version published as Reguty kierowania umysłem. Poszukiwanie prawdy poprzez światło naturalne. Translated by Ludwik Chmaj. Kęty: Antyk, 2002.

JUDYCKI, Stanisław. "Doświadczenie i rozum.” Accessed February 23, 2020. https://www.kul.pl/ files/57/wydzial/judycki/Judycki_2009a.pdf.

MCMullin, Ernan. 2008. "Explanation as Confirmation in Descartes's Natural Philosophy." In A Companion to Descartes, edited by Janet Broughton and John Carriero, 84-102. Malden, MA: Blackwell Publishing.

MoraWIEC, Edmund. 1965. “O dedukcji u Kartezjusza.” Studia Philosophiae Christianae 1 (1): 175-97.

MorawiEC, Edmund. 1967. "O intuicji intelektualnej u Kartezjusza.” Studia Philosophiae Christianae 3 (2): 195-213.

MiLes, Murray. 2008. “Descartes's Method.” In A Companion to Descartes, edited by Janet Broughton and John Carriero, 145-63. Malden, MA: Blackwell Publishing.

Mursell, James L. 1919. "The Function of Intuition in Descartes' Philosophy of Science." The Philosophical Review 28 (4): 391-409.

Newman, Lex. 2019. "Descartes' Epistemology.” In The Stanford Encyclopedia of Philosophy (Spring 2019 Edition), edited by Edward N. Zalta. Accessed February 7, 2020. https://plato.stanford.edu /archives/spr2019/entries/descartes-epistemology.

PATterson, Sarah. 2008. "Clear and Distinct Perception." In A Companion to Descartes, edited by Janet Broughton and John Carriero, 216-34. Malden, MA: Blackwell Publishing.

RORTY, Richard. "Intuition." In The Encyclopedia of Philosophy, edited by Paul Edwards, 4:204-12. New York-London: Macmillan, Free Press, 1967. 2nd ed. (2005): 722-32.

WALCZAK, Monika. 2016. "Intuition and Insight. The Analysis of Their Selected Features with Reference to Bernard Lonergan Position.” Analiza i Egzystencja, no. 34, 29-44.

WALCZAK, Monika. 2011. "Intuicja jako typ poznania, wiedzy i dyspozycji.” In Zagadnienia Naukoznawstwa 47 (2): 127-44.

\section{EPISTEMIC FUNCTIONS OF INTUITION IN DESCARTES}

\section{S u m m a r y}

The topic of the paper is the notion of intuition in Descartes' philosophy and its epistemic functions. Descartes introduces his notion of intuition in the context of a description of his method and process of knowing and doing science. Intuition is a significant component of this process. I intend to show that the main epistemic functions of intuition in Descartes' philosophy are differentiated. Intuition is essential not only in the context of justification (the Cartesian synthetic method of proof) but also and especially in the context of discovery (the Cartesian analytic method of discovery) It plays not only a role in the foundation of the cogito but also on different stages of constructing the system of knowledge. Intuition has important functions in grasping simple natures, forming pri- 
mary concepts, comprehending complex natures, forming primary propositions (including primary principles), and capturing relationships between them and building deductive reasoning (the role of intuition in deduction). Hence, intuition is the foundation for all primary stages of producing knowledge. It is active and important element of pure thinking (a priori) in human knowledge, and science. It fulfils these functions due to its specific epistemic properties. I also argue that intuition is not an autonomous and complete type of knowledge. Nor is it an intuitive thesis, but rather the basis of a justification for theses (including the cogito).

Keywords: intuition; epistemic functions; cognition; knowledge.

\section{EPISTEMICZNE FUNKCJE INTUICJI U KARTEZJUSZA}

\section{Streszczenie}

Przedmiotem artykułu jest pojęcie intuicji w filozofii Kartezjusza i jej epistemiczne funkcje. Kartezjusz wprowadza pojęcie intuicji w kontekście charakterystyki metody i procesu poznania oraz uprawiania nauki. Intuicja jest istotnym składnikiem tego procesu. Celem artykułu jest wykazanie, że główne epistemiczne funkcje intuicji w filozofii Kartezjusza są zróżnicowane. Jest ona niezbędna nie tylko w kontekście uzasadnienia (kartezjańska syntetyczna metoda dowodowa), ale przede wszystkim w kontekście odkrycia (kartezjańska analityczna metoda odkrycia). Odgrywa rolę nie tylko w fundowaniu cogito, lecz także na różnych etapach budowania systemu wiedzy. Intuicja pełni ważne funkcje w ujmowaniu prostych natur, tworzeniu pierwotnych pojęć, ujmowaniu złożonych natur, formułowaniu pierwotnych sądów (w tym pierwszych zasad), ujmowaniu relacji między nimi i przeprowadzaniu dedukcyjnych rozumowań (rola intuicji w dedukcji). Stąd intuicja jest fundamentem wszystkich podstawowych etapów tworzenia wiedzy. Stanowi czynny i ważny element czystego myślenia (a priori) w tworzeniu wiedzy ludzkiej i w nauce. Spełnia te funkcje dzięki specyficznym epistemicznym własnościom. W tekście argumentuję również, że intuicja nie jest autonomicznym i kompletnym typem poznania. Nie należy jej rozumieć jako twierdzenia intuicyjnego, ale raczej jako podstawę do uzasadniania tez (włącznie z cogito).

Słowa kluczowe: intuicja; epistemiczne funkcje; poznanie; wiedza. 